\title{
Conservation of the brown howler monkey in south-east Brazil
}

\author{
Adriano Garcia Chiarello and Mauro Galetti
}

The brown howler monkey Alouatta fusca once had a wide geographical distribution throughout a large part of the Atlantic forest in Brazil. Today only 5 per cent of these forests remain and the species is endangered. Howler monkeys can thrive in small forest fragments but they are more vulnerable to hunting, disease, and predation in these habitats than in undisturbed forests. Brown howler monkeys are important seed dispersers of several plant species, particularly in isolated forest fragments where specialized frugivores are absent. In protected areas without large predators howlers can reach high densities and the management of these populations is necessary to avoid inbreeding.

\section{Introduction}

The Atlantic forest of Brazil originally extended from the state of Rio Grande do Norte to the southernmost borders of the country, into the northern Argentinian province of Missiones and parts of eastern Paraguay. This forest once covered more than 1 million sq $\mathrm{km}$, making it the third most extensive vegetation type in Brazil after the Amazonian forest and the cerrado (Mittermeier et al., 1989). This ecosystem has been exploited since Europeans arrived in Brazil in 1500 and today only 5 per cent remains (Mittermeier et al., 1989).

The Atlantic forest is a very rich ecosystem, second only to the Amazon basin in diversity of Neotropical primate species (Mittermeier $e t$ al., 1989), with about 15 species of six genera, including the brown howler monkey Alouatta fusca, the woolly spider monkey Brachyteles arachnoides, the masked titi Callicebus personatus and the golden-lion tamarin Leontopithecus rosalia, which are endemic.

Alouatta fusca is one of the least known species of howler monkeys. In contrast with the mantled howler monkey A. palliata of Central America, which has been studied since the 1930s, and the red howler A. seniculus of northern South America, which has been studied since the late 1960s, field studies on free-ranging brown howler monkeys started only recently (Mendes, 1989; Prates et al., 1990; Chiarello, 1992; Galetti, 1992). The species occurs in southern Bahia, Espírito Santo, eastern Minas Gerais, Rio de Janeiro, São Paulo, Paraná, Santa Catarina and northern Rio Grande do Sul in Brazil, as well as in the extreme north-east of Argentina (Figure 1).

Ihering (1914) recognized two subspecies, the northern brown howler $A$. fusca fusca from Bahia, northern Espírito Santo and north-eastern Minas Gerais, and the southern form $A$. fusca clamitans, which occurs from eastern Minas Gerais and adjacent parts of Espírito Santo south to the state of Rio Grande do Sul and Argentina (Figure 2). Ihering's (1914) separation of the two populations was based on the lack of sexual dimorphism in pelage colour of the northern specimens. In A.f. fusca, adult males and females are both a pale rufous colour, while adult males of $A$. $f$. clamitans have rufous or golden fur and the adult females are dark brown. The validity of these two subspecies is controversial because pelage colour appears to be variable within populations (Mendes, 1989), but these two subspecies are still recognized by several authors (Kinzey, 1982; Mittermeier et al., 1988; Coimbra-Filho, 1990). However, there are insufficient data to establish their exact geographical distribution. Rylands et al. (1988), for 


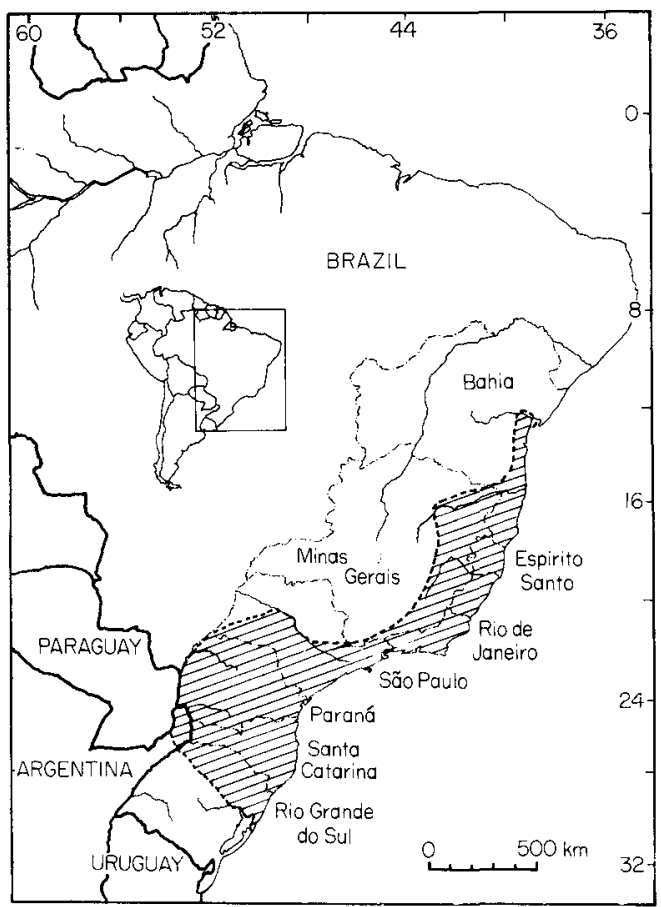

Figure 1. Approximate geographical distribution of the brown howler monkey (hatched area), based on museum specimens and field observations.

example, recently discovered that populations of both subspecies occur on the right bank of the Rio Jequitinhonha in north-eastern Minas Gerais (Figure 2), a region where $A$. f. clamitans was not known to occur previously (Ihering, 1914; Cabrera, 1958; Kinzey, 1982).

\section{Habitat, hunting and conservation status of the brown howler monkey}

The coastal and adjacent mesophytic forests inhabited by the brown howler monkey are located in heavily populated areas that have been exploited since the European colonization of Brazil. Because of the proximity of human settlements over this long period, this ecosystem is now found scattered in a few large and numerous small reserves. Habitat destruction has been caused chiefly by deforestation and selective logging, which is still widespread even in legally protected parks and reserves (Mittermeier et al., 1989).
The poaching of native fauna, although prohibited by federal law, is a serious problem for the brown howler monkey in poorly developed areas, such as north-east Minas Gerais and adjacent parts of Bahia and Espírito Santo as well as in south-east São Paulo. The Brazilian Government Environment Institute (IBAMA) is unable to patrol all the protected areas effectively. The surviving populations of brown howler monkeys are restricted to isolated forest fragments in federal, state and municipal parks and farms scattered throughout the eastern and south-eastern states of Brazil. With continuing deforestation and hunting in the already decimated Atlantic forest the species's population status has changed from 'relatively common' to 'threatened by extinction' (Mittermeier et al., 1982; Coimbra-Filho, 1990).

\section{The brown howler at Santa Genebra}

Detailed ecological studies of free-ranging brown howlers have been carried out at the Caratinga Biological Station, eastern Minas̀ Gerais (Mendes, 1989), the Itapuã State Park in Rio Grande do Sul (Prates et al., 1990), and at the Santa Genebra Reserve in the suburbs of Campinas, São Paulo (Chiarello, 1992; Galetti, 1992). The Santa Genebra Reserve is a 250-ha fragment of semi-deciduous forest surrounded by cultivated fields, where selective logging and occasional fires have occurred in the past. A consequence of these disturbances has been the proliferation of lianas throughout the forest (c. 130 species; L. P. Morellato, pers. comm.) and a reduction in the diversity of avian and mammalian species (Willis, 1979). The Santa Genebra Reserve is characteristic of a large part of the remaining habitat of the brown howler monkey.

The brown howlers studied in this forest show dietary adaptations to the disturbed nature of the habitat. One group of six individuals (one adult male, two adult females, two juveniles and one infant), consumed large amounts of leaves (73 per cent of the annual diet), of which a significant percentage came from lianas (41 per cent of the leaf diet), while 
Figure 2. Map of eastern Brazil showing the localities where the subspecies of brown howlers were recorded, based on museum specimens and field observations. The asterisk marks the position of the Santa Genebra Reserve, near Campinas (sources: 1, Cabrera, 1958; 2, Laemmert et al., 1946; 3, Coimbra-Filho, 1990; 4, Santos et al., 1987; 5, Rylands et al., 1988; 6, Vieira, 1955; 7, Mendes, 1989; 8, A. G. Chiarello, in prep.; 9 , Mendes, 1991; 10, Kinzey, 1982; 11, Mittermeier et al., 1982; 12 , Torres de Assumpção, 1982; 13, pers. observ.; 14, Vieira, 1944; 15 , Silva, 1981; 16, Napier, 1976; 17, Torres de Assumpção, 1983; 18, C. T. Carvalho, pers. comm.; 19 , Carvalho, 1979; 20, Chitolina and Sander, 1981; 21, Prates et al., 1990; 22, Crespo, 1954; 23, Hirsch et al., 1991).

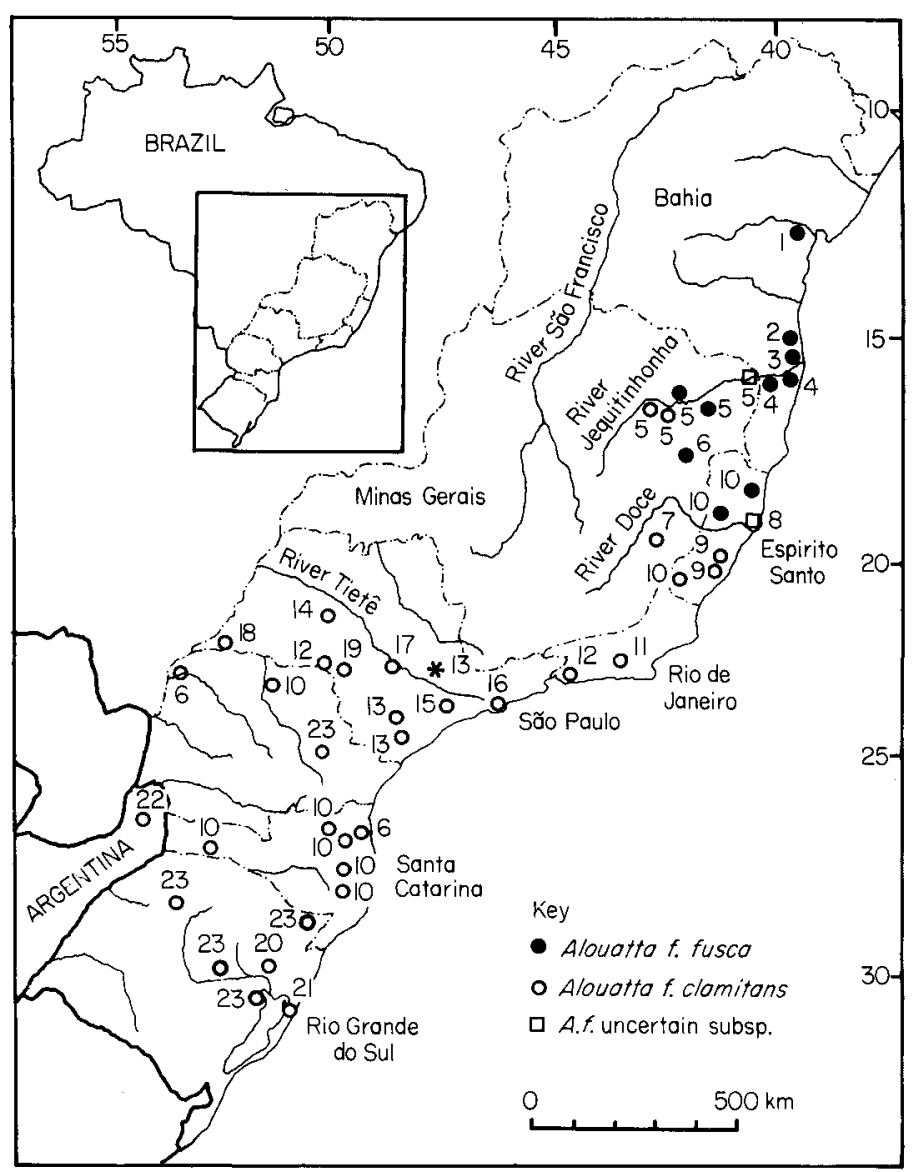

fruits contributed only 5 per cent to the diet annually (Chiarello, 1992). The brown howlers of Caratinga Biological Station, however, ingested a higher percentage of fruits (14 per cent of the annual diet; Mendes, 1989).

Compared with Santa Genebra, Caratinga is larger ( $570 \mathrm{ha}$ ) and, although the vegetation is also predominantly secondary, some tracts of primary forest still persist and the vegetation is not as densely invaded by lianas (S. L. Mendes, pers. comm.). Logging at Santa Genebra has probably decreased the number of tree species with fleshy fruits used by howlers, but a reduced diversity of fruits in the howlers' diet also reflects the low availability of fleshy fruits in semi-deciduous forests (Galetti, 1992). Accentuated folivory is known for other howler species, but generally they tend to ingest equivalent proportions of leaves and fruits; the leaves provide a source of proteins and the fruits readily available energy (Milton, 1980). It is probable that the scarcity of trees with fleshy fruits at Santa Genebra has led the brown howlers to increase the consumption of liana leaves, especially young ones, which are richer in water and readily available energy and lower in fibre than mature ones (Milton, 1980).

Howlers have been observed in extremely small forest fragments and are the only large frugivores that thrive in such areas (Lovejoy et al., 1986; Schwarzkopf and Rylands, 1989). They are considered to be important seed dispersers (Chapman, 1989) and undoubtedly play an important role as seed dispersers for large-fruited trees in small forest fragments, where large avian frugivores such as guans, toucans and cotingas, as well as other more frugivorous primates (notably Brachyteles arachnoides) are absent. At Santa Genebra, at 


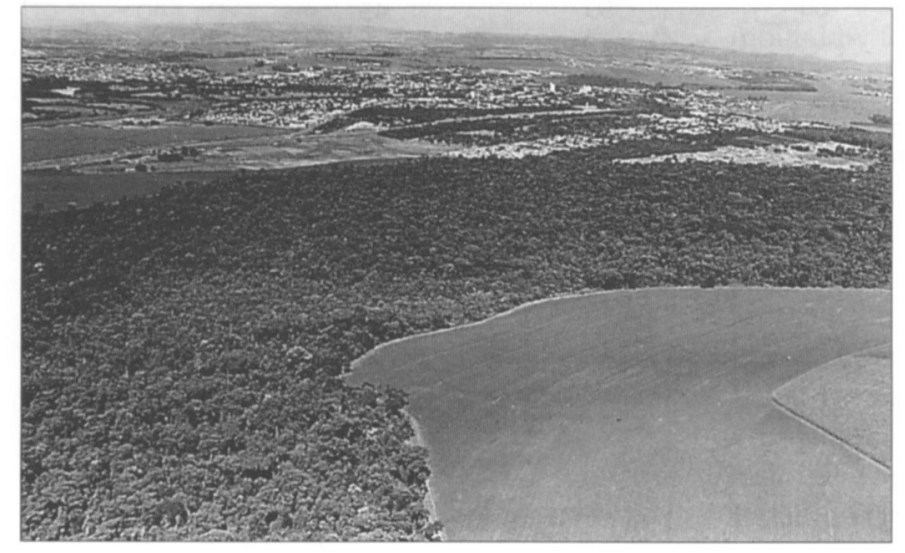

Aerial view of the Santa Genebra Reserve, Campinas, south-east Brazil, where ecological studies have been carried out with brown howler monkeys ( $N$. Chinalia). least seven fruits are dispersed mainly by brown howlers (Callophylum brasiliensis, Chrysophyllum sp., Cordia ecalyculata, Ocotea corimbosa, Cryptocarya moschata, Copaifera langsdorffii and Annona cacans). Howlers, therefore, may be important in the maintenance of seed dispersal of plants with large fruits in small areas that cannot support large and specialized frugivores.

The major natural predators of howlers (large cats and harpy eagles) do not occur at Santa Genebra and the only threat is feral dogs. Subadult individuals are probably more vulnerable because, while migrating to search for less densely occupied areas of the forest, they travel alone and descend to the ground more frequently than adults of established groups. But predation by feral dogs may be a rare event given that brown howlers are very hesitant to descend to the forest floor (pers. obs.). As a result of food abundance (liana leaves) and low predation pressure, the population of howlers has increased significantly in the last 20 years. The small home range of the study group ( $4.13 \mathrm{ha}$ ) was shared with five neighbouring groups, and preliminary estimates point to a total population of between 50 and 80 groups (1.19-1.77 individuals / ha) of apparently healthy individuals living at Santa Genebra (Chiarello, 1992). We do not know the density of howlers before the forest was isolated, but it was extremely low just before the creation of the reserve in the early 1980 s (K. S. Brown and I. Sazima, pers. comm.). The
Caratinga Biological Station also has a relatively high density of brown howlers (1.17 individuals/ha; Mendes, 1989) and, likewise, in the Brazilian Amazon red howlers have been found to be the only primate species to increase in number in newly created small forest fragments. Schwarzkopf and Rylands (1989) argued that howlers persist in small forest fragments because, compared with other Amazonian primates, they have a folivorous diet, a flexible home range size, and an ability to travel in small groups.

In contrast, brown howlers are present in lower densities (0.48-1.13 individuals/ha) in the Cantareira Reserve, a 5700-ha state reserve in eastern São Paulo (Silva, 1981). In other large Atlantic forest reserves in São Paulo, such as the Fazenda Intervales ( $38,000 \mathrm{ha})$ and the Carlos Botelho State Park (38,400 ha), and in the Rio Doce State Park in Minas Gerais $(30,000 \mathrm{ha})$ brown howlers are only rarely seen or heard (A. Hirsch, pers. comm.; pers. observ.), and their densities are very low. The species occurs at even lower densities in the larger reserves of southern Bahia (Santos et al., 1987) and northern Espirito Santo (for example, CVRD [Companhia Vale do Rio Doce] 22,000-ha forest reserve; A. G. C. unpubl. data) and in some places it is considered to be extinct (for example, in Sooretama Biological Reserve; Mendes, 1991). Like mantled howlers, brown howlers are susceptible to simian yellow fever (Deane, 1972), and epidemics of this disease, along with heavy 
poaching in the past, may have been responsible for the low densities found currently in these large forest reserves. However, the lower density of primates in large mature forests is still a mystery.

\section{Prospects for the future}

Small surviving populations of brown howler monkeys may not experience food shortages because the proliferation of lianas is a general phenomenon in forest fragments or selectively logged forests (Lovejoy et al., 1986). In the Santa Genebra Reserve, when fruits are scarce the brown howlers can use young liana leaves as a source of energy. The main threat seems to be the geographical isolation of these small populations, which in the long term could result in the absence of gene flow and a consequent decline in heterozygosity (Robinson and Ramirez, 1982). Basic data, such as population size and fecundity rates, are necessary to study the effects of inbreeding. Regrettably these data are still lacking; it is not known with certainty even in which parks and reserves the brown howlers still survive (see Mittermeier et al., 1982). The situation is the same for other threatened primate species that inhabit the Atlantic forest, such as the woolly spider monkey and the lion tamarin. The extent of our ignorance is demonstrated by the recent description of a new species of lion tamarin Leontopithecus caissara, which was discovered in a reserve less than $300 \mathrm{~km}$ from São Paulo, the most populated Brazilian city (Lorini and Persson, 1990). It is essential to know, therefore, where the brown howlers are thriving and the size of their populations. This can only be achieved through systematic censuses of primate species in protected areas. Without this basic knowledge we are unable to make any decision concerning management strategies, including measures such as the interchange of individuals between small isolated forests, which might be essential to prevent the deleterious effects of inbreeding and loss of species genetic variability.

\section{Acknowledgments}

We would like to thank the Fundação José Pedro de Oliveira for permission to work at the Santa Genebra Reserve, David Chivers and an anonymous reviewer for critical comments on the manuscript, and the Jornal Correio Popular for the aerial photograph. A. Chiarello was supported by $\mathrm{CNPq}$ and $\mathrm{M}$. Galetti by CAPES and FAPESP, and currently by a doctoral fellowship in Cambridge from $\mathrm{CNPq}$.

\section{References}

Cabrera, A. 1958. Catalogo de los mamiferos de America del Sur. Rev. Mus. Arg. Cienc. Nat. Bernardino Rivadavia, 4, 1-307.

Carvalho, C.T. 1979. Mamíferos dos parques e reservas de São Paulo. Silvic. São Paulo, 13, 49-72.

Chapman, C.A. 1989. Primate seed dispersal: the fate of dispersed seeds. Biotropica, 21, 148-154.

Chiarello, A.G. 1992. Dieta, padrão de atividades e área de vida de um grupo de bugios, Alouatta fusca, na reserva de Santa Genebra, Campinas, SP. MSc thesis, Universidade Estadual de Campinas, Campinas.

Chitolina, O. P. and Sander, M. 1981. Contribuição ao conhecimento da alimentação de Alouatta guariba clamitans Cabrera, 1940 em habitat natural no Rio Grande do Sul (Cebidae: Alouattinae). Iheringia Ser. Zool. 59, 37-44.

Coimbra-Filho, A.F. 1990. Sistemática, distribuição geográfica e situação atual dos símios brasileiros (Platyrrhini-Primates). Rev. Brasil. Biol. 50, 1063-1079.

Crespo, J.A. 1954. Presence of the reddish howler monkey (Alouatta guariba clamitans Cabrera) in Argentina. J. Mammal. 35, 117-118.

Deane, L.M. 1972. Simian malaria survey in Brazil, a brief summary of data obtained in 1964-1971. WHO-MAL 72 (774), 1-6.

Galetti, M. 1992. Sazonalidade na dieta de vertebrados frugivoros em uma floresta semidecídua no Brasil. MSc thesis, Universidade Estadual de Campinas, Campinas.

Hirsch, A., Landau, E.C., Tedeschi, A.C.M. and Menegheti, J. O. 1991. Estudo comparativo das especies do genero Alouatta Lacepede, 1799 (Platyrrhini, Atelidae) e sua distribuição geográfica na América do Sul. In A Primatologia no Brasil3 (eds A. B. Rylands and A. T. Bernardes), pp. 239-262. Sociedade Brasileira de Primatologia and Fundação Biodiversitas, Belo Horizonte.

Ihering, H. von. 1914. Os bugios do gênero Alouatta. Rev. Mus. Paulista. 9, 231-280.

Kinzey, W.G. 1982. Distribution of primates and forest refuges. In Biological Diversification in the Tropics (ed. G. T. Prance), pp. 455-482. Columbia University Press, New York. 
Laemmert, H.W., Jr., Ferreira, L.C. and Taylor, R.M. 1946. An epidemiological study of jungle yellow fever in endemic area in Brasil. Part II Investigation of Vertebrate hosts and arthropod vectors. Am. J. Trop. Med. 26, 23-69.

Lorini, M.L. and Persson, V.G. 1990. Nova espécie de Leontopithecus Lesson, 1840, do sul do Brasil (Primates, Callittichidae). Bol. Mus. Nac. nova serie, Zool. 338, 1-14.

Lovejoy, T.E., Bierregaard, R.O, Jr., Rylands, A.B., Malcolm, J.R, Quintela, C.E., Harper, L.H., Brown, K.S.; Jr., Powell, A.H., Powell, G.V.N., Schubart, H.O.R. and Hays, M.B. 1986. Edge and other effects of isolation on Amazon forest fragments. In Conservation Biology (ed. M. E. Soulé), pp. 257-285. Sinauer, Sunderland.

Mendes, S.L. 1989. Estudo ecológico de Alouatta fusca (Primates: Cebidae) na Estação Ecológica de Caratinga, MG. Rev. Nordestina Biol. 6, 71-104.

Mendes, S.L. 1991. Situação atual dos primatas em reservas florestais do estado do Espírito Santo. In A Primatologia no Brasil (eds A. B. Rylands and A. T. Bernardes),Vol. 3. pp. 347-356. Fundação Biodiversitas, Belo Horizonte.

Milton, K. 1980. The Foraging Strategy of Howler Monkeys. Columbia University Press, New York.

Mittermeier, R.A., Coimbra-Filho, A.F., Constable, I.D., Rylands, A.B. and Valle, C. 1982. Conservation of primates in the Atlantic forest region of eastern Brazil. Int. Zoo Yearbook. 22, 2-17.

Mittermeier, R.A., Rylands, A.B. and Coimbra-Filho, A.F. 1988. Systematics: species and subspecies An update. In Ecology and Behavior of Neotropical Primates (eds R. A. Mittermeier, A. B. Rylands, A. F. Coimbra-Filho and G. A. B. da Fonseca), Vol. 2. pp. 13-75. World Wildlife Fund, Washington.

Mittermeier, R.A., Kinzey, W.G. and Mast, R.B. 1989. Neotropical primate conservation. J. Hum. Evol. 18, 597-610.

Napier, P.H. 1976. Catalogue of Primates in the British Museum (Natural History) Part I: Families Callitrichidae and Cebidae. British Museum (Natural History), London.

Prates, J.C., Gayer, S.M.P., Kunz, L.F., Jr. and Buss, G. 1990. Feeding habits of the brown howler monkey Alouatta fusca clamitans (Cabrera, 1940) (Cebidae, Alouattinae) in the Itapuã State Park: a preliminary report. Acta Biol. Leopoldensia, 12, 175-188.
Robinson, J.G. and Ramirez, J.C. 1982. Conservation biology of neotropical primates. In Mammalian Biology in South America (eds M. A. Mares and H. H. Geonoways), pp. 329-344. University of Pittsburgh Press, Pittsburgh.

Rylands, A.B., Spironelo, W.R., Tornisielo, V.L., de Sa, R.L., Kierulff, M.C.M. and Santos, I.B. 1988. Primates of the Rio Jequitinhonha valley, Minas Gerais, Brazil. Primate Conserv. 9, 100-109.

Santos, I.B., Mittermeier, R.A., Rylands, A.B. and Valle, C.M.C. 1987. The distribution and conservation status of primates in southern Bahia, Brazil. Primate Conserv. 8, 126-142.

Schwarzkopf, L. and Rylands, A.B. 1989. Primate species richness in relation to habitat structure in Amazonian rainforest fragments. Biol. Conserv. 48, 1-12.

Silva, E.C., Jr. 1981. A preliminary survey of brown howler monkeys (Alouatta fusca) at the Cantareira Reserve (São Paulo, Brasil). Rev. Brasil. Biol. 41, 897-910.

Torres de Assumpção, C. 1982. Conservation of primates in Brasil: Atlantic forest primates. In Primate Conservation in the Wild, (ed. D. Harper), Vol. 1. pp. 34-48, University of Leicester, Leicester.

Torres de Assumpção, C. 1983. An Ecological Study of the Primates of Southeastern Brazil, with a Reappraisal of Cebus apella Races. PhD thesis, University of Edinburgh, Edinburgh.

Vieira, C.C. 1944. Os símios do estado de São Paulo. Pap. Avul. Zool. 4, 1-31.

Vieira, C.C. 1955. Lista remissiva dos mamíferos do Brasil. Arq. Zool. Est. São Paulo. 8, 341-464.

Willis, E.O. 1979. The composition of avian communities in remanescent woodlots in southern Brazil. Pap. Aoul. Zool. 33, 1-25.

Adriano Garcia Chiarello, AGG, Departamento de Zoologia, UNICAMP, CP 6109, 13083-970, Campinas, São Paulo, Brazil. Current address: Wildlife Research Group, University of Cambridge, Department of Anatomy, Downing Street, Cambridge, CB2 3DY, UK.

Mauro Galetti, Wildlife Research Group, University of Cambridge, Department of Anatomy, Downing Street, Cambridge, CB2 3DY, UK. 